\title{
Investigation on Spectroscopic, Thermal and Antimicrobial Activity of Newly Synthesized Binuclear Cr(III) Metal Ion Complex
}

\author{
M. R. Islam, J. A. Shampa, M. Kudrat-E-Zahan*, M. M. Haque, Y. Reza \\ Department of Chemistry, University of Rajshahi, Rajshahi-6205, Bangladesh \\ Received 9 January 2016, accepted in final revised form 2 February 2016
}

\begin{abstract}
Binuclear $\mathrm{Cr}$ (III) metal ion complex was synthesized using diphenylacetic acid as primary ligand and 2-methyl pyridine (2-picoline) as secondary ligand. The synthesized complex was characterized by conductivity, FTIR, UV-Vis spectroscopy, magnetic moment and thermogravimetric analysis (TGA). FTIR spectra indicated the coordination of deprotonated diphenylacetic acid and 2-picoline through nitrogen and oxygen. The presence of water molecules inside the coordination sphere of the complex was confirmed from IR spectrum and TGA analysis. Binuclear and octahedral structure of the $\mathrm{Cr}$ (III) complex confirmed by TGA, UV-Vis spectroscopy and magnetic moment measurement. The complex showed moderate antibacterial activity with no antifungal activity.
\end{abstract}

Keywords: Mixed ligand; Binuclear complex; $\mathrm{Cr}(\mathrm{III})$; TGA analysis.

๑) 2016 JSR Publications. ISSN: 2070-0237 (Print); 2070-0245 (Online). All rights reserved.

doi: http://dx.doi.org/10.3329/jsr.v8i2.26332 J. Sci. Res. 8 (2), 181-189 (2016)

\section{Introduction}

$\mathrm{Cr}$ (III) complexes have played an important historical role in the development of transition metal chemistry, primarily due to their relative kinetic inertness [1]. Cr(III) is an essential trace element for humans. Together with insulin, it removes glucose from the blood and plays a vital role in fat metabolism. Biological function of chromium is not fully known yet. The diabetes relevant interaction of $\mathrm{Cr}$ (III) is with the hormone insulin and its receptors. This suggests that $\mathrm{Cr}$ (III) acts with insulin on the first step in the metabolism of sugar entry into the cell, and facilitates the interaction of insulin with its receptor and the cell surface [2,3]. Chromium increases insulin binding to cells, insulin receptor number and activates insulin receptor kinase leading to increased insulin sensitivity [4]. Thus, chromium is an essential element

* Corresponding author: kudrat.chem@ru.ac.bd 
involved in glucose metabolism and diabetes [5]. Chromium is also known to activate enzymes, maintain protein stability. Organic $\mathrm{Cr}(\mathrm{III})$ sources have been shown to enhance the availability of chromium [6]. However, long exposure to $\mathrm{Cr}$ (III) compounds may result in dermatitis and liver or kidney damage in humans and is thereby toxic in large doses $[7,8]$.

The metal complexes with the ligand containing heterocyclic ring systems are very promising candidates for practical applications [9]. Synthesis, characterization and biological activities of mixed ligand complexes of some transition elements with Phthaliimides as primary and 2-picoline as secondary ligands have already been published [10,11]. Manimekala reported the synthesis and thermal stability of some mixed ligand complexes of transition metals with diphenylacetic acid and neutral hydrazine [12]. Reza et al. disclosed the crystal structure of mixed ligand copper complex formed with 2,2-bipyridine and diphenylacetic acid [13]. To the best of our knowledge, the research work on the mixed ligand complex of transition metals with diphenylacetic acid and 2-picoline is not reported yet.

Here, we have investigated the preparation and characterization of binuclear $\mathrm{Cr}$ (III) metal ion complex using diphenylacetic acid as primary ligand and 2-methyl pyridine (2-picoline) as secondary ligand. We also included the antibacterial and antifungal activity of the synthesized complex.

\section{Experimental}

\subsection{Instrumentation}

The weighing operation was performed on a METTLER PM 200 electronic balance. Infrared spectra were recorded on a FTIR-8400, SHIMADZU, Japan using a KBr disc, in Central Science Lab of Rajshahi University. The Sherwood Scientific susceptibility balance was used for magnetic susceptibility measurement. The melting point or decomposition temperature of the prepared metal complex was observed with the Tlectrothermal ${ }^{\circledR}$ Melting Point Apparatus. It was however, not possible to measure the melting points beyond $300^{\circ} \mathrm{C}$. The thermogravimetric analysis (TGA) was performed on Perkin Elmer Simultaneous Thermal Analyzer, STA-8000. All conductivity readings were measured by Horiba B-173 compact conductivity meter. The electronic spectrum of the complex in solution phase $(9.82 \times 10-4 \mathrm{M})$ was recorded on a Shimadzu Double Beam spectrophotometer model UV-1200 and UV-1650PC.

\subsection{Synthesis of binuclear $\mathrm{Cr}(\mathrm{III})$ complex, $\left[\mathrm{Cr}_{2}(\mathrm{DiPhAc})_{2}(2-\mathrm{pic})_{2}\left(\mathrm{H}_{2} \mathrm{O}\right)_{5}\right] \mathrm{Cl}_{2}$}

$2 \mathrm{mmol}(0.436 \mathrm{~g})$ of diphenylacetic acid was dissolved in absolute alcohol to which 2 mmol (0.187 g) 2-picoline was added. Then $2 \mathrm{mmol}(0.202 \mathrm{~g})$ triethylamine was added and the mixture was stirred for $10 \mathrm{~min}$. After that an ethanolic solution of $2 \mathrm{mmol}$ $(0.574 \mathrm{~g})$ of $\mathrm{CrCl}_{3} \cdot 6 \mathrm{H}_{2} \mathrm{O}$ was added to the mixture while stirring with magnetic stirrer. 
The stirring was continued for $6 \mathrm{~h}$ at $60^{\circ} \mathrm{C}$ and then cooled to room temperature. Thus, the ppt. formed was filtered, washed several times with alcohol and dried in a vacuum desiccator over anhydrous $\mathrm{CaCl}_{2}$.

\section{Results and Discussions}

\subsection{Decomposition temperature/melting point}

Decomposition temperature/melting point give an approximate idea about the nature of the complexes and can suggest whether it is covalent or ionic. Also with comparing initial materials m.p./decomposition temperature can predict preliminary whether any reaction occurs or not. We found that the synthesized complex $\left[\mathrm{Cr}_{2}(\mathrm{DiPhAc})_{2}(2-\right.$ $\left.\mathrm{Pic})_{2}\left(\mathrm{H}_{2} \mathrm{O}\right)_{5}\right] \mathrm{Cl}_{2}$ is having decomposition temperature above $300^{\circ} \mathrm{C}$ which indicated the formation of a stable coordination compound of $\mathrm{Cr}(\mathrm{III})[14,15]$.

\subsection{Magnetic moment}

The measurements of magnetic susceptibilities were made at constant temperature 304 $\mathrm{K}$, Curie-law was used and was calculated from the equation. $\mu_{\text {eff }}=2.828 \sqrt{\chi_{\mathrm{m}}^{\text {corr }} . \mathrm{T}}$ B.M. Thus $\mu_{\text {eff }}$ obtained is known as effective magnetic moment. The magnetic moment of this complex was determined on the solid as $\mu_{\text {eff }}=3.79$ B.M., which corresponds to three unpaired electrons and indicate that the synthesized $\mathrm{Cr}$ (III) complex is paramagnetic and might be having octahedral geometry [16-18].

\subsection{Molar conductance}

The value of molar conductance in $\mathrm{ohm}^{-1} \mathrm{~cm}^{2} \mathrm{~mol}^{-1}$ indicates the charge type of electrolyte. The molar conductance of $9.82 \times 10^{-4} \mathrm{M}$ solution of the complex in DMSO was measured at $29^{\circ} \mathrm{C}$. The molar conductance values $115 \mathrm{ohm}^{-1} \mathrm{~cm}^{2} \mathrm{~mol}^{-1}$ indicated that the complex is good 1:1 electrolyte [19].

\subsection{Infrared spectra}

The spectrum of free diphenylacetic acid shows a broad absorption near 3568-3106 $\mathrm{cm}^{-1}$ which indicated the presence of $\mathrm{v}(\mathrm{O}-\mathrm{H})$ group. There was also a $\mathrm{C}-\mathrm{O}$ single bond band at $1215 \mathrm{~cm}^{-1}$ and the $v(\mathrm{C}=\mathrm{O})$ band at $1705 \mathrm{~cm}^{-1}$. The spectra of free 2-picoline shows band at $1693 \mathrm{~cm}^{-1}$ assigned to $v(\mathrm{C}=\mathrm{N})$ [20]. The complex displays bands at $1563 \mathrm{~cm}^{-1}$ and $1600 \mathrm{~cm}^{-1}$ due to $v_{\text {sym }}(\mathrm{C}=\mathrm{O})$ and $v_{\text {asy }}(\mathrm{C}-\mathrm{O})$ respectively, significantly lower than those of free diphenylacetic acid indicating the coordination of acid through its carboxylate anions. A broad band observe at $3200-3600 \mathrm{~cm}^{-1}$ is due to $v(\mathrm{O}$ $\mathrm{H})$ for free acid. The disappearance of the $v(\mathrm{O}-\mathrm{H})$ mode observe in the free acid molecule clearly indicate the loss of the protons from both $\mathrm{O}-\mathrm{H}$ groups upon 
coordination, revealing that acid are negative bidentate ligand coordinating through carboxylate anions. Several absorptions of similar intensity at $3068 \mathrm{~cm}^{-1}$ to $2950 \mathrm{~cm}^{-1}$ indicate the presence of two $v(\mathrm{M}-\mathrm{O})$ in the complex [21] and an absorption near 3606 $\mathrm{cm}^{-1}$ indicate the presence of a bridged water ligand [22].

Further the presence of $\mathrm{M}-\mathrm{O}$ bonding is evident from the appearance of $v(\mathrm{M}-\mathrm{O})$ modes at $431-585 \mathrm{~cm}^{-1}$ in the spectra of the complex. The in-plane and out of plane ring deformation modes of the heterocyclic amines observe at $\sim 700 \mathrm{~cm}^{-1}$ undergo a positive shift in mixed ligand complexes confirming thereby coordination through nitrogen. The presence of $v(\mathrm{M}-\mathrm{N})$ bonding in the complex is also evident from appearance of $v(\mathrm{M}-\mathrm{N})$ modes at $747 \mathrm{~cm}^{-1}$ in the spectrum of the complex.

\section{5. $U V$-Vis spectra}

The UV-Vis spectra of the complex $\left[\mathrm{Cr}_{2}(\mathrm{DiPhAc})_{2}(2-\mathrm{Pic})_{2}\left(\mathrm{H}_{2} \mathrm{O}\right)_{5}\right] \mathrm{Cl}_{2}, \mathrm{CrCl}_{3} \cdot 6 \mathrm{H}_{2} \mathrm{O}$, diphenylacetic acid and 2-methyl pyridine (2-picoline) are shown in Fig. 1. The ligand 2-picoline shows transition at $204 \mathrm{~nm}$ for the presence of $(\mathrm{C}=\mathrm{N})$ as $\pi \rightarrow \pi^{*}$ and transitions occurred at $256 \mathrm{~nm}$ to $270 \mathrm{~nm}$ for the presence of conjugated double bonds. Diphenylacetic acid shows transitions at, $260 \mathrm{~nm}$ and $266 \mathrm{~nm}$ for $n \rightarrow \sigma^{*}$ and $n \rightarrow \pi^{*}$, The assignment of the geometrical configuration of some $\mathrm{Cr}$ (III) complexes with mixed ligands can be suggested by inspection of the $d-d$ absorption spectra $[23,24]$. The UV spectrum of $\mathrm{CrCl}_{3} \cdot 6 \mathrm{H}_{2} \mathrm{O}$ in DMSO shows two d-d transition at $14970 \mathrm{~cm}^{-1}$ $(668 \mathrm{~nm})$ and $21322 \mathrm{~cm}^{-1}(469 \mathrm{~nm})$. The reflectance spectra of $\mathrm{Cr}(\mathrm{III})$ complex consist of three transition bands at $260 \mathrm{~nm}, 410 \mathrm{~nm}$ and $574 \mathrm{~nm}$ assignable to the transitions ${ }^{4} A_{2 g} \rightarrow{ }^{4} T_{2 g},{ }^{4} A_{2 g} \rightarrow{ }^{4} T_{1 g}(F)$ and ${ }^{4} A_{2 g} \rightarrow{ }^{4} T_{1 g}(P)$ respectively. These transitions of the complex have occurred at significantly higher energy state (lower wavelength). The spectrum of the complex is further supported by the magnetic moment of the complex and predicted the octahedral structure of the complex $\left[\mathrm{Cr}_{2}(\mathrm{DiPhAc})_{2}(2-\mathrm{Pic})_{2}\right.$ $\left.\left(\mathrm{H}_{2} \mathrm{O}\right)_{5}\right] \mathrm{Cl}_{2}[25]$.

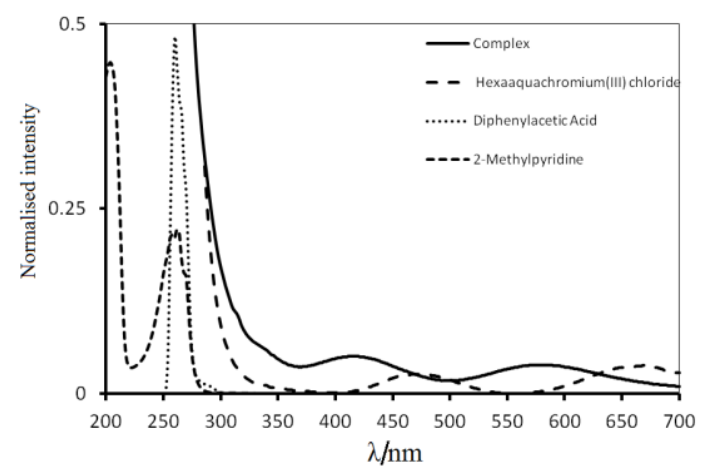

Fig. 1. UV spectra of complex $\left[\mathrm{Cr}_{2}(\mathrm{DiPhAc})_{2}(2-\mathrm{Pic})_{2}\left(\mathrm{H}_{2} \mathrm{O}\right)_{5}\right] \mathrm{Cl}_{2}, \mathrm{CrCl}_{3} \cdot 6 \mathrm{H}_{2} \mathrm{O}$, diphenylacetic acid and 2-methyl pyridine (2-picoline). 


\subsection{Thermogravimetric analysis}

TGA was carried out for solid complex $\left[\mathrm{Cr}_{2}(\mathrm{DiPhAc})_{2}(2-\mathrm{Pic})_{2}\left(\mathrm{H}_{2} \mathrm{O}\right)_{5}\right] \mathrm{Cl}_{2}$, under $\mathrm{N}_{2}$ flow and heating rate was suitably controlled at $30^{\circ} \mathrm{C} \mathrm{min}^{-1}$ and the weight loss was measured from the ambient temperature upto $800^{\circ} \mathrm{C}$. The TGA curve of the complex is shown in Fig. 2. Tables 1-2 show the maximum temperature values $T_{\max } /{ }^{\circ} \mathrm{C}$, species lost together with the corresponding weight loss for each step of the decomposition reaction $[26,27]$. The data obtained strongly supported the proposed formulas of the complex. The data from the TGA clearly indicated that the decomposition of the complex proceeds in four or five steps. In the first step of decomposition two chlorine atoms were lost between $30^{\circ} \mathrm{C}$ to $\sim 331^{\circ} \mathrm{C}$ (calculated $8.10 \%$, experimental $7.75 \%$ of weight) [28,29]. Four molecules of coordinated water molecules are gradually decomposed between temperatures $332^{\circ} \mathrm{C}$ to $384.4^{\circ} \mathrm{C}$ (calculated $8.508 \%$, experimental $8.85 \%$ of weight) in second step of decomposition [30]. Monodentate two 2-picoline ligands were decomposed in third step at $385^{\circ} \mathrm{C}$ to $658^{\circ} \mathrm{C}$ (calculated $21.29 \%$, experimental $24.69 \%$ of weight). Bridging diphenylacetic acid and water molecules are to be decomposed as biphenyl ketone and hydrogen atom respectively at $>650{ }^{\circ} \mathrm{C}$ in fourth or fifth stage of decomposition and $\mathrm{Cr}_{2} \mathrm{O}_{3}$ assumed to be formed at high temperature [31]. The proposed degradation pathway, supported by TGA curve and data in Fig. 3 showing order and steps of possible elimination of atoms and groups from the synthesized $\mathrm{Cr}(\mathrm{III})$ complex.

Table 1. Thermogravimetric data of synthesized complex.

\begin{tabular}{llll}
\hline Entry & Step & $\begin{array}{l}\text { Temperature range } \\
\left({ }^{\circ} \mathrm{C}\right)\end{array}$ & $\begin{array}{l}\text { Weight loss } \\
\text { found (calculated })(\%)\end{array}$ \\
\hline$\left[\mathrm{Cr}_{2}(\mathrm{DiPhAc})_{2}(2-\right.$ & First & $30-331$ & $7.75(8.10)$ \\
pic $\left.)_{2}\left(\mathrm{H}_{2} \mathrm{O}\right)_{5}\right] \mathrm{Cl}_{2}$ & Second & $332-384.41$ & $8.85(8.508)$ \\
& Third & $385-658$ & $24.69(21.29)$ \\
& Fourth & $>650$ & $(44.58)$ \\
& Fifth & $>650$ & $(0.23)$ \\
\hline
\end{tabular}

Table 2. The TGA data of the complex (thermal decomposition).

\begin{tabular}{llllllll}
\hline Temperature & 100 & 200 & 300 & 400 & 500 & 600 & 700 \\
$\left({ }^{\circ} \mathrm{C}\right)$ & $\&$ & $\&$ & $\&$ & $\&$ & $\&$ & $\&$ & $\&$ \\
& 150 & 250 & 350 & 450 & 550 & 650 & 750 \\
\hline Complex & \multicolumn{7}{l}{ Weight loss $(\%)$} \\
& & & & & & \\
\hline$\left[\mathrm{Cr}_{2}(\mathrm{DiPhAc})_{2}(2-\right.$ & 99.62 & 98.23 & 94.83 & 78.26 & 64.68 & 60.31 & 58.38 \\
pic $\left.)_{2}\left(\mathrm{H}_{2} \mathrm{O}\right)_{5}\right] \mathrm{Cl}_{2}$ & $\&$ & $\&$ & $\&$ & $\&$ & $\&$ & $\&$ & $\&$ \\
& 98.88 & 97.17 & 89.20 & 67.64 & 62.05 & 58.90 & 58.30 \\
\hline
\end{tabular}




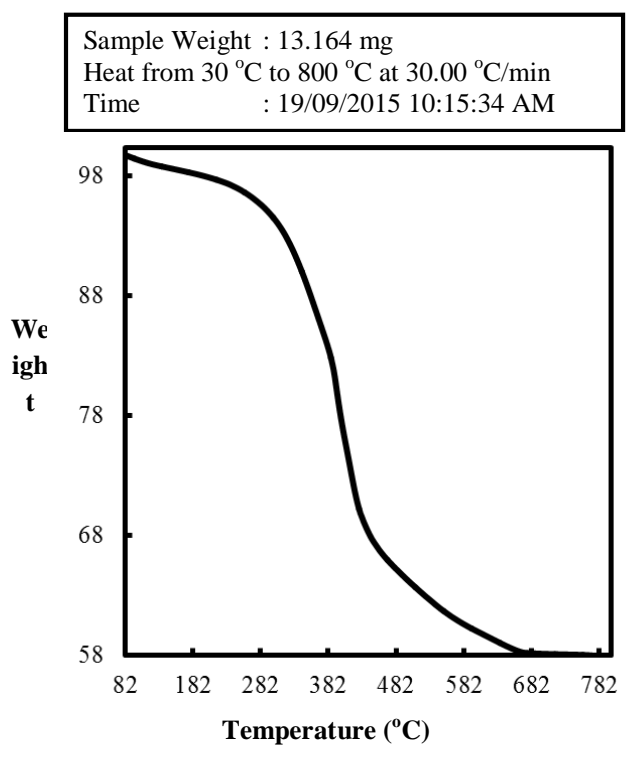

Fig. 2. TGA pattern of complex $\left[\mathrm{Cr}_{2}(\mathrm{DiPhAc})_{2}(2-\mathrm{pic})_{2}\left(\mathrm{H}_{2} \mathrm{O}\right)_{5}\right] \mathrm{Cl}_{2}$.

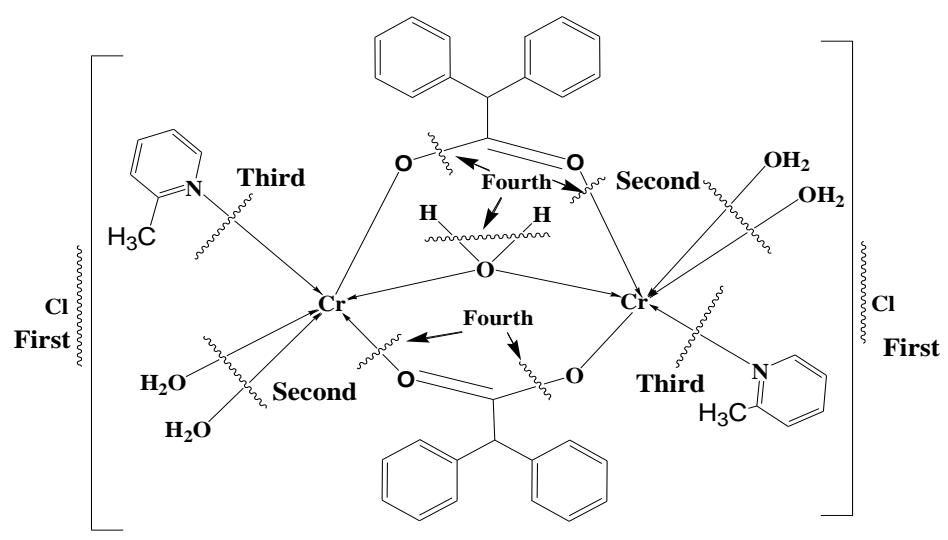

Fig. 3. A possible degradation pathway of complex $\left[\mathrm{Cr}_{2}(\mathrm{DiPhAc})_{2}(2-\mathrm{Pic})_{2}\left(\mathrm{H}_{2} \mathrm{O}\right)_{5}\right] \mathrm{Cl}_{2}$.

\subsection{Chloride $\left(\mathrm{Cl}^{-}\right)$test}

The reaction of the synthesized complex with $\mathrm{AgNO}_{3}$ gave white precipitate, and this result showed presence of Chloride $\left(\mathrm{Cl}^{-}\right)$in outer coordination sphere. This result is also consistent with the molar conductance values $115 \mathrm{ohm}^{-1} \mathrm{~cm}^{2} \mathrm{~mol}^{-1}$. 


\subsection{Antimicrobial activity}

Any chemical or biological agent that either destroys or inhibits the growth of microorganisms is called antimicrobial agent. The susceptibility of microorganism to antimicrobial agent can be determined in vitro by a number of methods. The disc diffusion technique [32] is widely acceptable for preliminary investigations of materials which are suspected to possess antimicrobial properties. Diffusion procedure, as normally used in essentially a qualitative test, which allocates organism of the susceptible, intermediate (moderately susceptible) or resistant categories. The antibacterial activities of the test complexes were determined by using the dose of 20 $\mu \mathrm{g} / \mathrm{disc}$. The complexes showed strong sensitivity against both gram positive and gram negative bacteria and the results were compared with antibiotic disc of Streptomycin. The synthesized $\mathrm{Cr}$ (III) complex showed antibacterial activity in zone of inhibition diameter as $13 \mathrm{~mm}, 12 \mathrm{~mm}$, and $12 \mathrm{~mm}$ against Bacillus subtilis, Escherichia coli and Proteus volgaris respectively. The complex hasn't shown any antifungal activity against Fusarium filamentous fungi.

\section{Conclusion}

Magnetic moment data indicated that the complex is paramagnetic in nature having three unpaired electrons. Conductivity measurement indicated that the complex is good 1:1 electrolyte in nature. IR spectral data showed the ligands coordinate with metal atom through $\mathrm{O}$ and $\mathrm{N}$ atoms. TGA showed the thermal stability of complex and the data obtained from TGA strongly supported the proposed formula of the complex $[33,34]$. UV-Vis spectra of the synthesized $\mathrm{Cr}(\mathrm{III})$ complex confirmed the formation and octahedral structure of synthesized $\left[\mathrm{Cr}_{2}(\mathrm{DiPhAc})_{2}(2-\mathrm{Pic})_{2}\left(\mathrm{H}_{2} \mathrm{O}\right)_{5}\right] \mathrm{Cl}_{2}$ complex where two molecules of diphenylacetic acid and one molecule of water coordinated through $\mu_{2}$ bridging. Based on these facts a structure of complex $\left[\mathrm{Cr}_{2}(\mathrm{DiPhAc})_{2}(2-\right.$ Pic $\left.)_{2}\left(\mathrm{H}_{2} \mathrm{O}\right)_{5}\right] \mathrm{Cl}_{2}$ has been proposed as shown in Fig. 4.

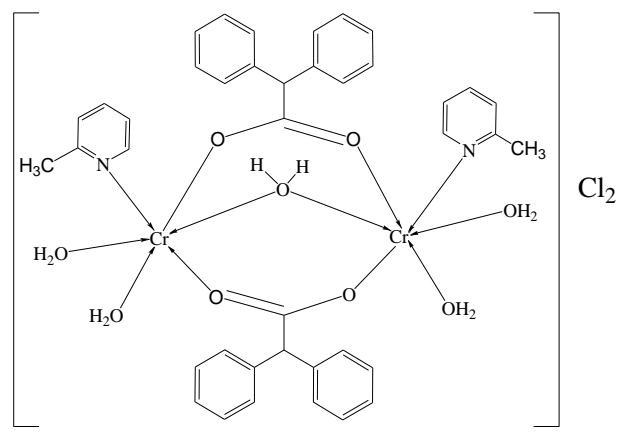

Fig. 4. Proposed structure of the synthesized $\left[\mathrm{Cr}_{2}(\mathrm{DiPhAc})_{2}(2-\mathrm{Pic})_{2}\left(\mathrm{H}_{2} \mathrm{O}\right)_{3}\right] \mathrm{Cl}_{2}$. 


\section{References}

1. F. A. Cotton and G. Wilkinson, Advanced Inorganic Chemistry, $5^{\text {th }}$ edition (Wiley, New York, 1988).

2. Z. Krejpcio, Polish J. Environ. Studies 10(6), 399 (2001).

3. J. B. Vincent, A History of Chromium Studies (1955-1995), The Nutritional Biochemistry of Chromium(III) (Elsevier, New York, 2007) .

4. R.A. Anderson, Chromium in the prevention and control of diabetes. Diabetes and Metabolism, 26, 22-27 (2000).

5. A. R. Kumar A, P. Riyazuddin, Microchem. J. 93, 236 (2009).

6. J. B. Vincent, Acc. Chem. Res. 33, 503 (2000). http://dx.doi.org/10.1021/ar990073r

7. J. E. Wahlberg and G. Wennersten, Br. J. Dermatol. 97, 411 (1977). http://dx.doi.org/10.1111/j.1365-2133.1977.tb14250.x

8. V. Murphy, S. A. M. Tofail, H. Hughes, and P. McLoughlin, Chem. Eng. J. 148, 425 (2009). http://dx.doi.org/10.1016/i.cej.2008.09.029

9. M. A. Subhan, F. Ahmed, M. S. Rahaman, A. K. Azad, and K. Begum, J. Sci. Res. 7(3),113 (2015). http://dx.doi.org/10.3329/jsr.v7i3.23270

10. L. A. Banu, M. S. Islam, M. A. A. Al-Bari and M. Kudrat-E-Zahan, Int. J. Adv. Multi. Res. 2(1), 145 (2015).

11. M. Kudrat-E-Zahan, M. M. Haque, L. Ahmmed, M. S. Ali, and M. S. Islam, Int. J. Mater. Sci. Appl. 4(2), 120 (2015).

12. R. Manimekalai, Int. J. Appl. Biol. Pharmaceut. Technol. 2(3), 268 (2011).

13. M. Y. Reza, L. A. Banu, M. S. Islam, S. W. Ng, and E. R. T. Tiekink, Acta Cryst. E67, m399 (2011). http://dx.doi.org/10.1107/S160053681100729X

14. M. Kudrat-E-Zahan, M. A. Bashar, M. F. Hossen, and M. S. Islam, AJRC 8(2), 74 (2015).

15. H. A. Bayoumi, A-N. M.A. Alaghaz, and M. S. Aljahdali, Int. J. Electrochem. Sci. 8, 9399 (2013).

16. D. L. Maples, R. D. Maples, W. A. Hoffert, T. H. Parsell, A. V. Asselt, J. D. Silversides, S. J. Archibald, and T. J. Hubin, Inorganica Chimica Acta 362, 2084 (2009). http://dx.doi.org/10.1016/j.ica.2008.09.034

17. F. A. Cotton and G. Wilkinson, Advanced Inorganic Chemistry, $3^{\text {rd }}$ edition (John Wiley and Sons, Canada, 1972) 838.

18. R.L. Carlin, Magnetochemistry (Springer-Verlag, Berlin, 1986). http://dx.doi.org/10.1007/978-3-642-70733-9

19. M. B. Hossain, M. S. Islam, M. R. Islam, M. A. Salamd, and M. A. Yousuf, J. Bangl. Chem. Soc. 25(2), 139 (2012).

20. N. N. Greenwood and K. Wade, J. Chem. Soc. 232, 1130 (1960). http://dx.doi.org/10.1039/jr9600001130

21. B. Šopotrajanov, V. Stefov, M. Žugić, V. M. Petruševski, J. Mol. Struc. 482,109 (1999).

22. J. R. Carney, A. V. Fedorov, J. R. Cable, and T. S. Zwier, J. Phys. Chem. A 105, 3487 (2001). http://dx.doi.org/10.1021/jp003375f

23. J. -H. Choi, M. A. Subhan, and S. W. Ng, J. Inorg. Gen. Chem. 638(2), 433 (2012).

24. S. A. Sadeek, M. S. El-Attar, and N. S. Abd El-Lattif, Bull. Chem. Soc. Ethiop. 28(1), 53 (2014). http://dx.doi.org/10.4314/bcse.v28i1.7

25. A. Debnath, F. Hussain, and D. T. Masram, Bioinorg. Chem. Appl. Article ID 457478, (2014).

26. D. Gürbüz, A. Çinarli, A. Tavman, and A. S. B. Tan, Bull. Chem. Soc. Ethiop. 29(1), 63 (2015). http://dx.doi.org/10.4314/bcse.v29i1.6

27. V. K. Sharma and S. Srivastava, Turk. J. Chem. 30, 755 (2006).

28. M. Shabbir, Z. Akhter, A. Gul, and M. Bolte, J. Chem. Soc. Pak. 36(1), 56 (2014).

29. S. M. El-Megharbel, J. Microb. Biochem. Technol. 7(2), 65 (2015).

30. A. W. Bauer, D. M. Perry, and W. M. M. Kirby, A. M. A. Arch. Intern. Med. 104, 208 (1959). http://dx.doi.org/10.1001/archinte.1959.00270080034004 
31. M. S. Masoud, S. A. A. EI-Enein, and H. M. Kamel, Ind. J. Chem. 41A, 297 (2002).

32. A. Sharma, T, Mehta, and M. K. Shah, Der Chemica Sinica 4(1), 141 (2013). 